\title{
Whole-body DXA evaluation in HIV patients
}

\author{
Mihai Lazăr ${ }^{1,2 *}$, Daniela Munteanu', Raluca Mihăilescu', Cătălin Tilişcan ${ }^{1,2}$, Tudorița Mărgineanu', \\ Ana-Maria Tudor ${ }^{1,2}$, Loredana Benea ${ }^{1}$, Anca Streinu-Cercel ${ }^{1,2}$, Ștefan Sorin Aramă2 ${ }^{2}$, Adrian Streinu-Cercel ${ }^{1,2}$, \\ Victoria Aramă ${ }^{1,2}$, Daniela Adriana lon ${ }^{2}$ \\ From The 10th Edition of the Scientific Days of the National Institute for Infectious Diseases "Prof Dr Matei Bals" \\ Bucharest, Romania. 15-17 October 2014
}

\section{Background}

After the introduction of highly active antiretroviral therapy for the treatment of HIV infection, metabolic abnormalities were increasingly observed, associated with both protease inhibitors and nucleoside reverse transcriptase inhibitors, characterized by abnormal fat distribution in the body (lipoatrophy, lipohypertrophy or both), hyperglycemia and lean tissue mass wasting. However such metabolic changes are not always treatment related, having a multifactorial etiology. Dual-energy X-ray absorptiometry (DXA) evaluates the quantity of body fat and lean tissue and their distribution, allowing the diagnosis of both quantitative and qualitative changes.

\section{Methods}

We evaluated 58 patients (26 females and 33 males), aged between 19 and 65 years, by whole body DXA scan. Biological tests on the patients included: leptin, adiponectin, resistin, TNFa, IL6, LT CD4+, viral load. Body mass index, waist/hip ratio and waist/height ratio were also calculated.

\section{Results}

We obtained significant correlations between the DXA data and the biological, clinical parameters, type and duration of the treatment.

\section{Conclusion}

DXA represent an essential tool in evaluation of HIV lipodystrophy and wasting syndrome and can be used for both treatment monitoring and disease metabolic evaluation of HIV patients.

\footnotetext{
* Correspondence: mihai.i.lazar@gmail.com

${ }^{1}$ National Institute for Infectious Diseases "Prof. Dr. Matei Balş", Bucharest, Romania

Full list of author information is available at the end of the article
}

\section{Acknowledgement}

The study was funded by the National Authority for Scientific Research (Grant No. 62077/2008, 2008-2011). Coordinating center: National Institute for Infectious Diseases Prof. Dr. Matei Balş, Bucharest, Romania.

\section{Authors' details}

"National Institute for Infectious Diseases "Prof. Dr. Matei Balş", Bucharest, Romania. ${ }^{2}$ Carol Davila University of Medicine and Pharmacy, Bucharest, Romania.

Published: 15 October 2014

doi:10.1186/1471-2334-14-S7-O4

Cite this article as: Lazăr et al:: Whole-body DXA evaluation in HIV patients. BMC Infectious Diseases 2014 14(Suppl 7):O4.

\section{Submit your next manuscript to BioMed Central and take full advantage of: \\ - Convenient online submission \\ - Thorough peer review \\ - No space constraints or color figure charges \\ - Immediate publication on acceptance \\ - Inclusion in PubMed, CAS, Scopus and Google Scholar \\ - Research which is freely available for redistribution \\ Submit your manuscript at www.biomedcentral.com/submit}

C Biomed Central (c) 2014 Lazăr et al; licensee BioMed Central Ltd. This is an Open Access article distributed under the terms of the Creative Commons Attribution License (http://creativecommons.org/licenses/by/4.0), which permits unrestricted use, distribution, and reproduction in any medium, provided the original work is properly cited. The Creative Commons Public Domain Dedication waiver (http://creativecommons.org/publicdomain/zero/1.0/) applies to the data made available in this article, unless otherwise stated. 